\title{
OCT4 is up-regulated by DNA hypomethylation of promoter in recurrent gliomas
}

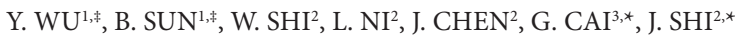 \\ ${ }^{1}$ Pediatrics Lab, Research Center of Clinical Medicine, Affiliated Hospital of Nantong University, 20 Xisi Road, Nantong, Jiangsu Province, \\ 226001, People's Republic of China; ${ }^{2}$ Department of Neurosurgery, Affiliated Hospital of Nantong University, 20 Xisi Road, Nantong, Jiangsu \\ Province,226001, People's Republic of China; ${ }^{3}$ Department of Neurosurgery, the First People's Hospital of Nantong, 6 Haier Xiang Road, Nantong, \\ Jiangsu Province,226001, People's Republic of China
}

*Correspondence: shij@ntu.edu.cn,ntshij@163.com

${ }^{*}$ Contributed equally to this work.

Received September 19, 2015 / Accepted December 1, 2015

\begin{abstract}
OCT4, a marker of embryonic stem cells, is also a key transcription factor that plays a regulatory role in the self-renewal, proliferation and differentiation of stem cells. Previous studies showed that DNA methylation is involved in the regulation of OCT4 expression during the development and differentiation of embryonic stem cells. However, DNA methylation in the promoter region of OCT4 has not yet been discussed in human recurrent glioma. In this study, we assessed the specimens from 24 cases of recurrent glioma for OCT4 expression and methylation status, and commenced analyzing the correlation between the two by treating glioma cells with a demethylating agent in vitro. The results demonstrated that for the same cases, the expression of OCT4 in specimens of recurrent glioma was significant higher than that in primary glioma $(P<0.05)$. DNA methylation levels in recurrent glioma decreased obviously compared with that in primary glioma $(t=9.800, P=0.008)$. In vitro study indicated, following demethylation treatment, glioma cells had an increased OCT4 expression. These results suggest that DNA hypomethylation may be a key mechanism underlying the up-regulation of OCT4 in the recurrence of glioma, which facilitates the understanding of the role of stem cells and the exploration of novel strategies for the treatment of recurrent glioma.
\end{abstract}

Key words: glioma, recurrence, OCT4,hypomethylation

Glioma is the most common tumor in the central nervous system. According to the histopathological and clinical criteria of WHO, glioma can be classified as grade I IV. Glioma of grade II IV has the characteristics of malignancies and usually presents poor prognosis $[1,2]$. With the development of modern medicine, great progression has been made in the diagnosis and treatment of malignant glioma. However, the prognosis has not been significantly improved and the recurrence of glioma is still inevitable [3-5].

Glioma stem cells (GSCs) are tumor cells possessing the characteristics and heterogeneity of stem cells [3], which are closely related to the occurrence, progression and outcome of brain tumors $[6,7]$. Research has found that GSCs maintain the growth of brain tumors in the long term and play an important role in tumor recurrence following conventional therapies. At present, surgical resection combined with radiotherapy or chemotherapy cannot radically eliminate GSCs $[8,9]$. Besides, the changes of local tumor microenvironment caused by surgery and other unknown reasons may make residual GSCs accumulate at the affected site. These GSCs will further differentiate into glioma cells, finally leading to recurrence of the glioma $[10,11]$.

OCT4 (OCT3/4, POU5F1) is an important member of the POU family of transcription factors. The OCT4 gene is localized on chromosome 6P21.3, and the OCT4 protein is encoded by POU5F1 [12]. In 1991 it was first discovered that OCT4 mRNA and OCT4 protein were expressed in oocytes before and after fertilization. Now recognized as the marker in embryonic and germ cells, OCT4 maintains cell plasticity and promotes the self-renewal and proliferation of stem cells [13]. Other studies show that OCT4 is also expressed in adult glioma and other tumors [14], 
but not in differentiated cells. So it is inferred that OCT4 helps maintain the current status of cancer stem cells and inhibits further differentiation [15-17]. These findings shed new light onto the stem cell theory of tumor occurrence. However, the expression of OCT4 and its role in recurrent glioma are rarely studied.

Epigenetic regulation is a mode of gene expression that affects gene transcription activity but does not involve DNA sequence changes. It is one of the chief regulatory mechanisms for gene transcription [18]. Among these regulatory mechanisms, DNA methylation has drawn wide attention. DNA methylation is a chemical modification regulated by enzymes, which mainly occurs in CpG islands. High-intensity methylation usually predicts a reduction of transcriptional activity, while low-intensity methylation is exactly the opposite [19]. Interpreting the epigenetic information carried by DNA methylation may be of great importance to understanding the mechanism of tumor occurrence and progression [20]. As found by numerous studies, high-intensity methylation occurring in the promoter region of a gene is connected with glioma occurrence. Overmethylation is also related to the signaling pathways involved in the occurrence, progression and histopathological typing and grading of glioma [21-24]. During the course of mouse and human embryonic development and embryonic stem cell (ESC) differentiation, DNA methylation and histidine modification may regulate OCT4 expression [25-27]. However, DNA methylation in the promoter region of OCT4 has not yet been discussed in human recurrent glioma.

Therefore, we speculate that DNA methylation is involved in the regulation of OCT4 expression in recurrent glioma. We assessed the specimens from 24 cases of recurrent glioma for OCT4 expression and methylation status, and then commenced analyzing the correlation between the two by treating glioma cells with a demethylating agent in vitro.

\section{Patients and methods}

Patient selection and sampling. All the investigations described in this study were conducted after informed consent was obtained and in accordance with an institutional review board protocol approved by the ethics committee at the Affiliated Hospital of Nantong University. 24 patients with recurrent glioma were recruited from the Department of Neurosurgery, Afiiliated Hospital of Nantong University from January 2010 to December 2014. Recurrence of glioma was defined as the presence of glioma at $>3$ months after surgery for primary glioma. All patients received chemoradiotherapy after the first surgical intervention. Pathological findings were determined by more than 2 pathologists and classified according to the WHO classification standard (Table 1). The tissues of primary and recurrent glioma were collected and fixed in $10 \%$ formaldehyde followed by embedding in paraffin. In addition, a fraction of samples was placed into liquid nitrogen for use.
Glioma cells and demethylation treatment. U87MG and U251MG, the two human glioma cell lines, were purchased from the Shanghai Cell Institution of Chinese Academic Sciences. They were maintained in Dulbecco's Modified Eagle Medium: Nutrient Mixture F-12 (MDEM/F12) supplemented with $10 \%$ heat-inactivated fetal bovine serum (FBS), $100 \mathrm{U} / \mathrm{ml}$ penicillin and $100 \mu \mathrm{g} / \mathrm{ml}$ streptomycin (Gibco). Cells were incubated at $37^{\circ} \mathrm{C}$ in a humidified $5 \% \mathrm{CO}_{2}$ air atmosphere. When cell culture reached 50\% confluence, U87MG and U251MG cells were treated with 5-Aza-2'-deoxycytidine (5-Aza-dc, A3656; Sigma-Aldrich, St. Louis, MO, USA) at the final concentration of $10 \mathrm{nM}$ for 3 days, respectively.

RNA isolation and real-time PCR. RNA expression levels of OCT4 were determined using quantitative real-time PCR with GAPDH as positive controls. Total mRNA was isolated from glioma specimens and cell lines using mRNA isolation Kit (Roche, UK), and the quantity and quanlity of mRNA was measured by ultraviolet spectrophotometry. Isolated mRNA (100 ng) from each sample was transcribed to complementary DNA (cDNA) using a First-strand cDNA Synthesis Kit (Roche, UK), which was then used as a template for quantitative real-time PCR.

PCR primers (OCT4 fwd: 5'-TATTCAGCCAAACGACCATCT-3', rev: 5'-TCA GCTTCCTCCACCCACTT- 3'; GAPDH fwd: 5'-GGAAAGCTGTGGCGTGAT-3', rev: 5'-

Table 1. WHO grades of glioma patients

\begin{tabular}{lcc}
\hline \multirow{2}{*}{ patient } & \multicolumn{2}{c}{ WHO grade } \\
\cline { 2 - 3 } & primary & recurrent \\
\hline 1 & II & II \\
2 & IV & IV \\
3 & II & IV \\
4 & III & III \\
5 & III & IV \\
6 & II & IV \\
7 & III & IV \\
8 & II & II \\
9 & III & IV \\
10 & IV & IV \\
11 & IV & IV \\
12 & III & III \\
13 & II & II \\
14 & IV & IV \\
15 & IV & IV \\
16 & IV & IV \\
17 & III & III \\
18 & II & IV \\
19 & II & III \\
20 & II & IV \\
21 & IV & IV \\
22 & IV & IV \\
23 & IV & IV \\
24 & IV & IV \\
\hline & &
\end{tabular}


AAGGTGGAAGAATGGGAGTT-3') were designed using Primer5.0 software and synthesized by TIB molbiol. A $20 \mu \mathrm{l}$ reaction, which included $2 \mu \mathrm{l}$ DNA template, $2 \mu \mathrm{l}$ forward and reverse primer, $6 \mu \mathrm{LEPC} \mathrm{H}_{2} \mathrm{O}$ and $10 \mu \mathrm{l}$ SYBR Green Mix (QPK-201, Toyobo), was conducted using the ABI Prism 7500 Sequence Detection System (Applied Biosystems). PCRs of each template were performed in duplicate in a 96 well plate. The thermal cycling conditions included an initial denaturation step at $95^{\circ} \mathrm{C} 5 \mathrm{~min}$ and 40 cycles at $95^{\circ} \mathrm{C}$ for $10 \mathrm{sec}$, at $59^{\circ} \mathrm{C}$ for $15 \mathrm{sec}$ and at $72^{\circ} \mathrm{C}$ for $20 \mathrm{sec}$. The relative fold-change $2^{-\Delta \Delta C T}$ method was used to determine the relative quantitative gene expression compared with GAPDH. The transcription level of target genes observed in calibrating samples was treated as the basal level and given the value 1.0. All PCR reactions were performed in triplicate and a negative control was included that contained primers without cDNA.

Western blot analysis. The samples were homogenized in lysis buffer (1\% NP-40, $50 \mathrm{mmol} / \mathrm{l}$ Tris, $\mathrm{pH}$ 7.5, $5 \mathrm{mmol} / \mathrm{l}$ EDTA, $1 \%$ SDS, $1 \%$ sodium deoxycholate, $1 \%$ Triton X-100, $1 \mathrm{mmol} / \mathrm{l} \mathrm{PMSF}, 10 \mathrm{mg} / \mathrm{mL}$ aprotinin, and $1 \mathrm{mg} / \mathrm{mL}$ leupeptin; Sigma, USA) and clarified by centrifuging for $20 \mathrm{~min}$ in a microcentrifuge at $4^{\circ} \mathrm{C}$. After determination of its protein concentration with the Bradfordassay (Bio-Rad, USA), the resulting supernatant ( $50 \mu \mathrm{g}$ of protein) was subjected to SDSpolyacrylamide gel electrophoresis (PAGE). The separated proteins were transferred to a polyvinylidine difluoridemembrane (Millipore Corp., USA) by a transfer apparatus at $350 \mathrm{~mA}$ for $2.5 \mathrm{~h}$. The membranes were first blocked and then incubated with the primary antibody described above for $2 \mathrm{~h}$ at room temperature. After washing three times, filters were incubated with horseradish peroxidase-conjugated human anti-mouse or anti-rabbit antibodies (Pierce) for $1 \mathrm{~h}$ at room temperature. Immunocomplexes were detected with an enhanced chemiluminescence system (NEN Life Science Products, USA). The Western blot experiments were repeated at least three times.

Immunohistochemistry. Each glioma was immunohistochemically examined for OCT4 nuclear staining using an avidin-biotin-peroxidase technique (Dako, LSAB+ SystemHRP). Specimens were cut serially into $4 \mu \mathrm{m}$ sections. Sections were dewaxed in xylene and rehydrated in graded ethanols. ALL sections were treated with $0.3 \%$ methanolic peroxide for 30 minutes to neutralize endogenous peroxidase. Antigen retrieval was performed by microwaving and incubating the tissue sections for 10 minutes in $0.1 \mathrm{~mol} / \mathrm{L}$ citrate buffer. With the primary rabbit polyclonal antibodies OCT4 (1:200, Abcam, USA), the sections were incubated overnight at $4^{\circ} \mathrm{C}$. With the secondary goat antirabbit immunoglobulin (Invitrogen, USA), the sections were incubated for $1 \mathrm{~h}$ at room temperature followed by streptavidin-peroxidase. Immunocomplexes were visualized by brown pigmentation via a standard 3 , 3-diaminobenzidine (DAB) protocol. Counterstaining was performed by hematoxylin. The substitution of PBS for primary antibodies was used as negative cotrols. Ten high-power fields were randomly chosen, and at least 300 tumor cells were counted per field. The tumor cells were irregular in size and in shape, filled with transparent homogeneous cytoplasm, obvious nuclear atypia with 1 to 2 distinct nucleoli. Mitotic figures were frequent. Percentage of cells showing positive staining in nuclei was designated as the OCT4 labeling index, as a percentage (\%). The staining procedures were repeated at least three times.

DNA preparation and Bisulfite genomic sequencing. With the proteinase $\mathrm{K}$ digestion and phenole-chloroform method, genomic DNA was extracted from frozen tissues [28]. Sodium bisulfite treatment of the extracted DNA was performed as previously described [29]. In brief, $10 \mu \mathrm{g}$ DNA in $50 \mu \mathrm{l} \mathrm{TE}$ was incubated with $5.5 \mu \mathrm{l}$ of $0.3 \mathrm{M} \mathrm{NaOH}$ at $37^{\circ} \mathrm{C}$ for $15 \mathrm{~min}$ and $95^{\circ} \mathrm{C}$ for $2 \mathrm{~min}$, and subjected to sodium bisulfite chemical treatment $(2.4 \mathrm{M}$ sodium metabisulfite; $0.5 \mathrm{mM}$ hydroquinone, $\mathrm{pH}$ 5.0; both from Sigma). Following incubation at $55^{\circ} \mathrm{C}$ for $4 \mathrm{~h}$, the treated DNA was purified using the SK1261 kit (Shenggong, China), desulfonated in $0.3 \mathrm{M} \mathrm{NaOH}$, neutralized to $\mathrm{pH} 7.0$ using $3 \mathrm{M}$ sodium acetate ( $\mathrm{pH}$ 5.2). The neutralized DNA was purified using SK1261 purification kit again, dissolved in TE buffer ( $\mathrm{pH}$ 8.0).

The primers (fwd: 5'-GGATTTGTATTGAGGTTTTGGAG-3', rev: 5'-TAACC CATCACCTCCACCAC-3') were designed to amplify the promoter and exon 1 from -234 to +46 for bisulfite genomic sequencing. An initial denaturation at $98^{\circ} \mathrm{C}$ for $4 \mathrm{~min}$ was followed by five PCR cycles of $94^{\circ} \mathrm{C}$ for $45 \mathrm{sec}, 68^{\circ} \mathrm{C}$ for $45 \mathrm{sec}$ and $72^{\circ} \mathrm{C}$ for $1 \mathrm{~min}$. The PCR was then completed with 35 cycles of $45 \mathrm{sec}$ at $95^{\circ} \mathrm{C}$, $45 \mathrm{sec}$ at $58^{\circ} \mathrm{C}$. The amplified products were gel-purified using the SK1261 kit and subjected to TA-cloning using pUC18-T vector (Shenggong, Biotechnology Co.). Ten clones for each case were selected for sequencing using BigDye version 3.1, and analyzed on automated DNA sequence analyzer (ABI Prism 3730; Applied Biosystems, Inc., Foster City, CA, USA). The cytosine or thymine residues at the $\mathrm{CpG}$ sites represented methylated or unmethylated status, respectively.

Statistical analysis. Statistical analysis was performed using SPSS 13.0 for Windows. Data is expressed as mean \pm SD. Paired $t$-test analysis was used to determine the differences of gene expression and methylation level between primary and recurrent tumor. All statistical tests were calculated in two-sided and a $P$-value $<0.05$ was considered statistically significant.

\section{Results}

Up-regulation of OCT4 mRNA and protein in recurrent glioma. OCT4 mRNA was expressed in all specimens from 24 cases with primary or recurrent glioma. For the same cases, the expression of OCT4 in specimens of recurrent glioma $(2.07 \pm 0.15)$ was higher than that in primary glioma $(1.01 \pm 0.12)$, and the difference was statistically significant ( $t=19.57, P=0.000$ ) (Fig. $1 \mathrm{~A})$. We also analyzed the prognostic value of OCT4 expression using cBioPortal 
A

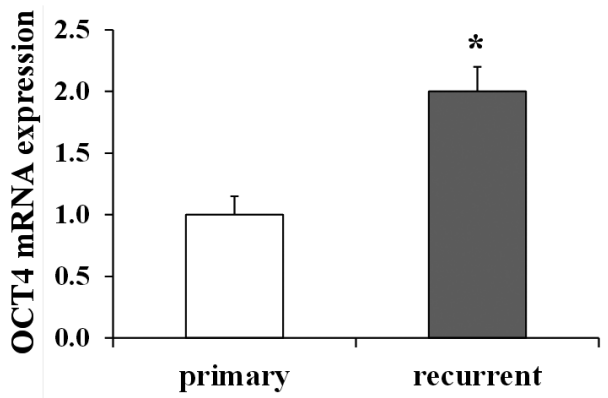

B

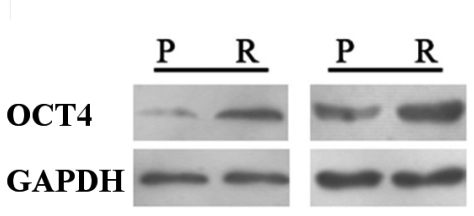

C

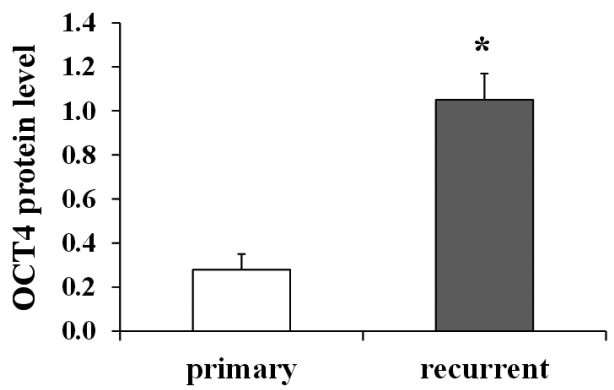

Figure 1. Up-regulation of OCT4 mRNA and protein in recurrent glioma. (A) Relative levels of OCT4 mRNA in primary (n=24) and recurrent gliomas $(\mathrm{n}=24)$ are shown as histograms. OCT4 $\mathrm{mRNA}$ expression was quantified by qRT-PCR compared with GAPDH. ${ }^{\star} P<0.05$. (B) Western blot detection of OCT4 protein levels in primary and recurrent gliomas. The blot shows representative results from primary and recurrent gliomas. GAPDH was used as a loading control. P: primary gliomas; $R$ : recurrent gliomas. (C) Statistical analysis of OCT4 protein in primary $(n=24)$ and recurrent gliomas $(n=24) .{ }^{\star}<0.05$.

software. The result turned to be negative $(P=0.094)$. During western blot detection, it was found that OCT4 protein level in recurrent glioma $(1.15 \pm 0.18)$ was obviously higher than that in primary glioma $(0.28 \pm 0.06)(t=19.86, P=0.000)$ (Fig. 1B, 1C).

Increased number of OCT4-positive cells in recurrent glioma measured immunohistochemically. The number of OCT4-positive cells in primary and recurrent glioma was detected immunohistochemically. According to the results, OCT4 was expressed in cell nuclei, and OCT4-positive cells were detected in all specimens (Fig. 2A). The percentage of OCT4-positive cells in primary and recurrent glioma was $3.79 \% \sim 79.67 \%$ and $14.64 \% \sim 98.07 \%$, respectively. Paired $t$-test indicated that the number of OCT4-positive cells in recurrent glioma $(56.90 \pm 24.36)$ was significantly higher than that in primary glioma $(37.23 \pm 26.50)(t=8.182, P=0.003)$ (Fig. 2B).

Reduced DNA methylation of the OCT4 gene in recurrent glioma. By means of BSP (Bisulfite Genomic Sequencing, BSP) $11 \mathrm{CpG}$ dinucleotides were analyzed. The promoter region contained eleven $\mathrm{CpG}$ dinucleotides (Fig. 3A). DNA methylation occurred to OCT4 in all specimens. The DNA methylation level in primary glioma and recurrent glioma was $52.73 \% \sim 81.82 \%$ and $23.64 \% \sim 74.55 \%$ (Fig. 3B, 3C), respectively. Statistical analysis indicated that DNA methylation levels in recurrent glioma $(57.61 \pm 13.95) \%$ decreased obviously compared with that in primary glioma $(65.96 \pm 11.42)$ $\%(t=9.800, P=0.008)$.

Up-regulation of OCT4 after treatment with demethylating agent. U87MG and U251MG glioma cell lines were treated with the demethylating agent 5-Aza-dc in vitro. As a result of treatment, OCT4 mRNA expression in U87 cells was up-regulated by 3.38 times, and up-regulated by 2.35 times in U251 cells (Fig. 4A). Expression of the OCT4 protein was detected by western blot, and it was found that the changes of OCT4 protein expression in the two types of cells were similar to those of OCT4 mRNA (Fig. 4B, 4C).
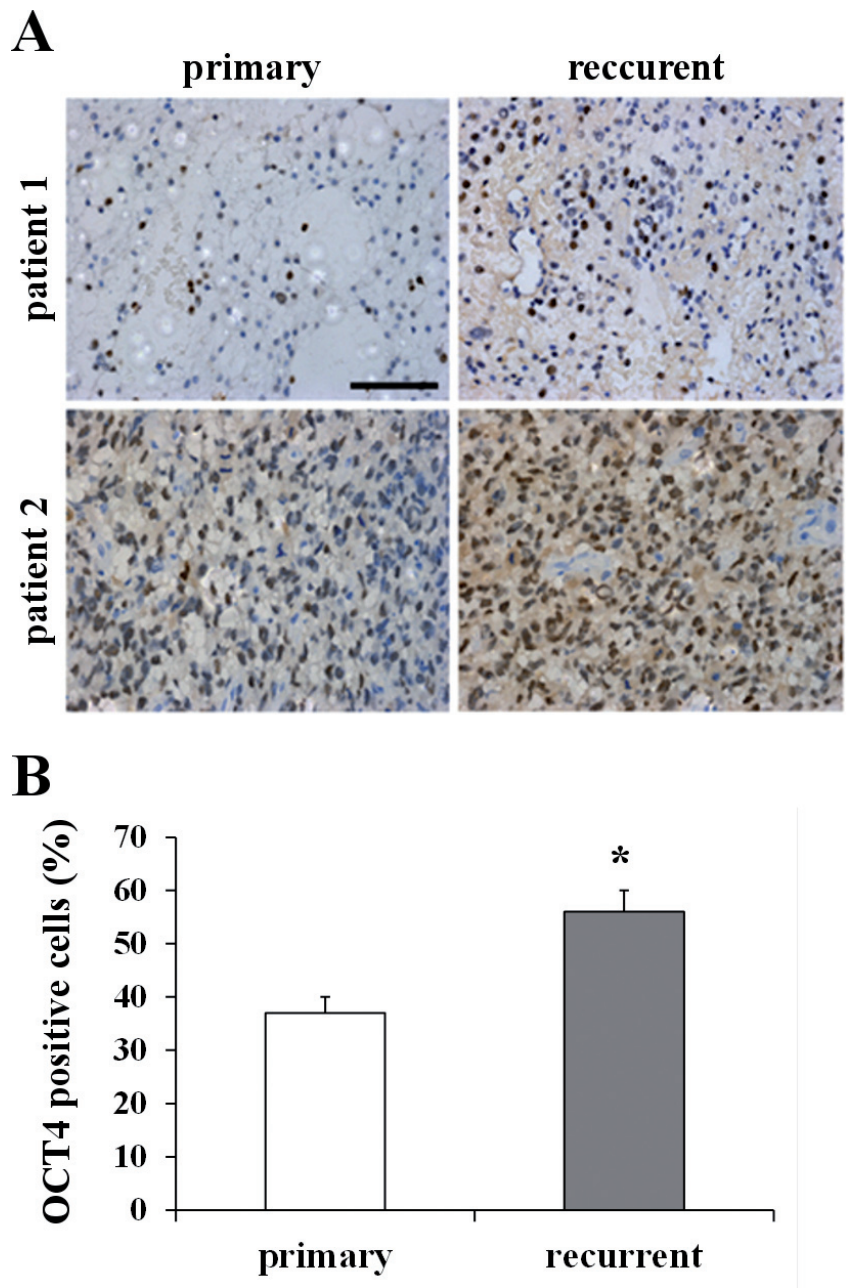

Figure 2. Increased percentage of OCT4-positive cells in recurrent glioma measured immunohistochemically. (A) OCT4 expression in paraffin-embedded sections from primary and recurrent gliomas immunohistochemically. OCT4 expression was primarily localized in the nuclei of tumor cells (brown). Scale bar $=100 \mu \mathrm{m}$. (B) Statistical analysis of the percentage of OCT4-positive cells in primary $(n=24)$ and recurrent gliomas $(n=24) .{ }^{\star} P<0.05$. 
A

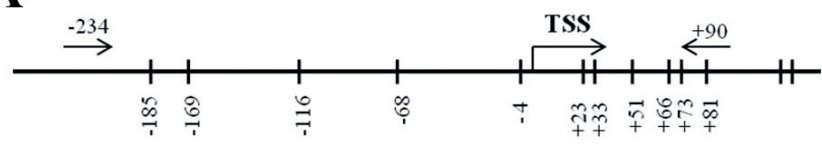

B

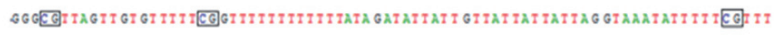

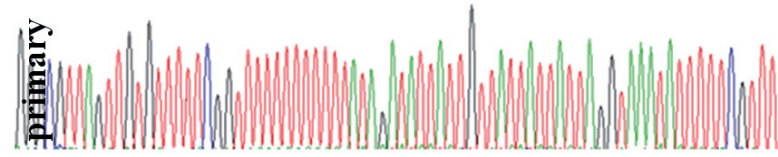

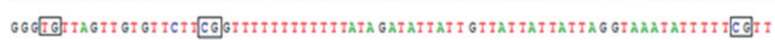

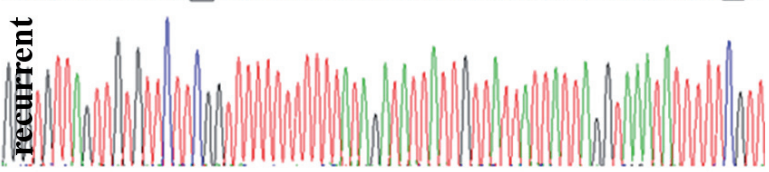

C

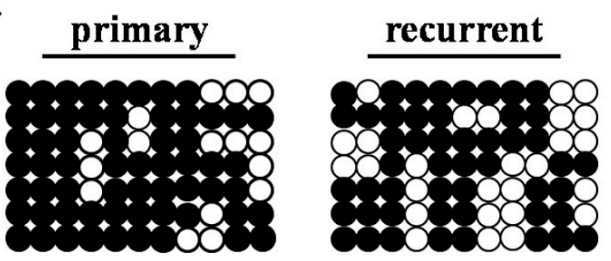

Figure 3. Reduced DNA methylation of the OCT4 gene in recurrent glioma. (A) DNA methylation profile of $11 \mathrm{CpG}$ dinucletides $(-234$ to +90$)$ located in the promoter region. $(\mathrm{B}, \mathrm{C})$ Analysis of DNA methylation at 11 known differentially methylated CpG sites in the OCT4-234 to +90 region with DNA from primary gliomas and recurrent gliomas. Black and white circles represent methylated and unmethylated sites, respectively.

\section{Discussion}

In recent years, stem cell-like cells have been identified in glioma and found to be related to tumor initiation or tumor recurrence or both [30]. Stem cell-like cells can invade into the brain tissues surrounding the glioma or interstitial tissues
[31-33]. Under certain conditions, stem cell-like cells may even migrate into the contralateral hemisphere [34]. The stem cell-like cells have no evident biological features of tumor cells. Although there seems to be a boardline between the tumor and the normal tissues, completely resection of GSCs under a microscope is seems to be impossible [30]. Neveretheless, the residual GSCs are insensitive to post-operative chemotherapy and radiotherapy [35]. Following surgery, a lot of inflammatory cytokines are produced, and angiogenesis, proliferation of glioma cells and surgery induced changes in local microenvironment and other unknown factors may cause recruitment of residual GSCs into the surgical site. GSCs then proliferate and differentiate into glioma cells, leading to the recurrence of glioma [36].

OCT4, a transcription factor, which has been found to be a marker of stem cells, is essential for the maintenance of stem cell plasticity and plays important roles in the self-renewal and differentiation of stem cells [35]. During the tumorigenesis of some cancer stem cells in adults, OCT4 expression is detectable and the OCT4 expression level is found to be consistent with the number of cancer stem cells and closely related to the malignant degree, development and prognosis of tumors [37]. In NSCs and glioma cells, OCT4 is also detectable, but OCT4 expression is not present in the neurons and glia cells. Moreover, Ikushima $\mathrm{H}$ et al. found that OCT4 maintains tumorigenicity of gliomainitiating cells in cooperation with the Sox axis [38]. Thus, the OCT4 expressing cells might be the tumor-initiating cells.

In the present study, OCT4 expression was detected in the glioma and higher in recurrent glioma than in primary glioma. These findings supported the GSC theory of glioma recurrence $[39,40]$. However, when we analyzed the prognostic value of OCT4 expression on glioma, the result turned to be negative. Although the result did not show the definite relationship between them, we believe that the OCT4 level may be related to the recurrence glioma. In the recurrent glioma, the proportion of GSCs is relatively high and these cells have more potential of self-renewal and proliferation, which may produce more cancer stem cells or daughter cells possessing potential of proliferation and growth. These characteristics are consistent with the clinical manifestations and pathological features of recurrent glioma.
A

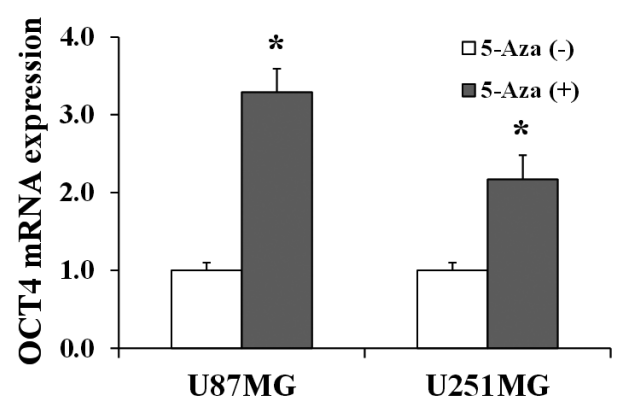

B

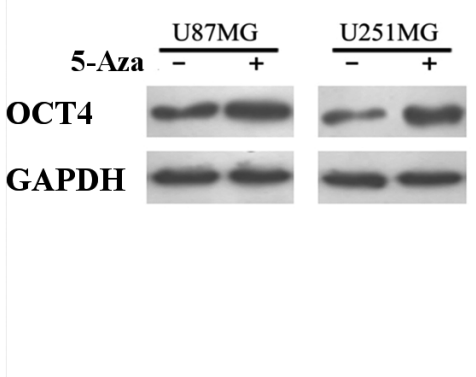

C

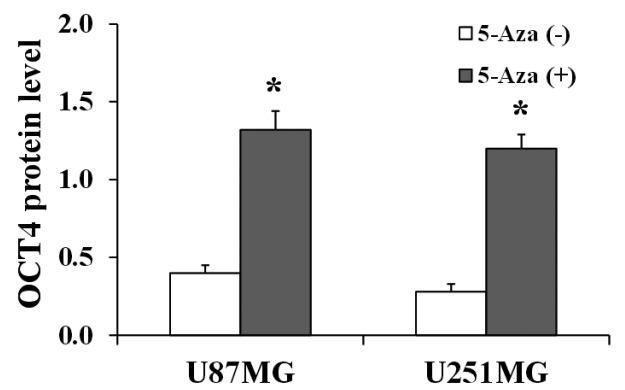

Figure 4. Up-regulation of OCT4 after treatmeat with demethylating agent in glioma cell lines. The glioma cell lines (U87MG and U251MG) were treated with 5-Aza-dc for $72 \mathrm{~h}$. (A) qRT-PCR analysis of $O C T 4 \mathrm{mRNA}$ expression. ${ }^{\star} P<0.05$. (B) Western blot analysis of $\mathrm{OCT} 4$ protein expression. GAPDH was used as a loading control. (C) Statistical analysis of OCT4 protein in U87MG and U251MG. ${ }^{\star} P<0.05$. 
During the differentiation of embryonic stem cells, teratocarcinoma, neural stem cells and the embryonic development of rats and humans, the DNA methylation of OCT4 gene at the gene regulatory region is a key regulatory factor in the transcription of OCT4 [27]. At the state of stem cells, the promoter of OCT4 gene undergoes demethylation, leading to the evident transcription and expression. With the differentiation of these cells, the promoter is highly methylated and the expression is reduced subsequently. Thus, OCT4 gene expression is almost undetectable in mature cells.

To explore whether the changes in OCT4 expression in recurrent glioma is related to the DNA methylation, BSP sequencing was employed to measure the methylation of promoter region $(-234 \sim+46)$. Results showed the methylation level of OCT4 gene was different in recurrent and primary glioma. And the methylation level in recurrent glioma was significantly reduced as compared to primary glioma, which was corresponding to the changes in mRNA and protein expressions of OCT4. In normal brain tissues, complete methylation was found at the targeted region. In glioma cell lines, following demethylation treatment, the mRNA and protein expressions of OCT4 were increased. These findings demonstrated that the DNA demethylation of OCT4 gene might be an important cause of up-regulation of OCT4 expression during the glioma recurrence. However, the changes in DNA methylation of OCT4 gene and the further reduction in methylation level in recurrent glioma are unclear and required to be confirmed. We speculate that the methylation level in glioma is reduced and the changes in local environment following surgery and radiotherapy/ chemotherapy may be an important cause of demethylation of OCT4 gene at regulatory region [41-43].

Taken together, our findings demonstrate DNA methylation of OCT4 gene in recurrent glioma is an important mechanism of up-regulated expression of OCT4, a key transcription factor, which may be involved in the recurrence of glioma. These results support the stem cell theory on glioma recurrence and provide evidence on the role of DNA methylation in the recurrence of glioma, providing directions for the clinical treatment of glioma.

Acknowledgments: This study was supported by the Youth Fund of the National Natural Science Foundation of China (81201975), the Youth Fund of the Natural Science Foundation of Jiangsu Province (BK2012224) and the Six Major Human Resources Project of Jiangsu Province (2011-WS-065, 2013-WSN-077, 2014-WSW-031).

\section{References}

[1] LOUIS DN, OHGAKI H, WIESTLER OD, CAVENEE WK, BURGER PC, et al. The 2007 WHO classification of tumors of the central nervous system. Acta Neuropathol. 2007; 114: 97-106. http://dx.doi.org/10.1007/s00401-007-0243-4

[2] LOUIS DN, PERRY A, BURGER P, ELLISON DW, REIFENBERGER G, et al. International Society of Neuropathology--Haarlem consensus guidelines for nervous system tumor classification and grading. Brain Pathol. 2014; 24: 429-35. http://dx.doi.org/10.1111/bpa.12171

[3] STUPP R, MASON WP, VAN DEN BENT MJ, WELLER M, FISHER B, et al. Radiotherapy plus concomitant and adjuvant temozolomide for glioblastoma. N Engl J Med. 2005; 352: 987-96. http://dx.doi.org/10.1056/NEJMoa043330

[4] WEN PY, KESARI S. Malignant gliomas in adults. N Engl J Med 2008; 359: 492-507. http://dx.doi.org/10.1056/NEJM$\underline{\mathrm{ra} 0708126}$

[5] LIU HL, FAN CH, TING CY, YEH CK. Combining microbubbles and ultrasound for drug delivery to brain tumors: current progress and overview.Theranostics. 2014; 4: 432-44. http:// dx.doi.org/10.7150/thno.8074

[6] BINELLO E, GERMANO IM. Stem cells as the therapeutic vehicles for the treatment of high-grade gliomas. Neuro Oncol. 2012; 14: 256-65. http://dx.doi.org/10.1093/neuonc/nor204

[7] TURPIN A, SHARIF A, STOVEN L, BLOND S, MAURAGE $\mathrm{CA}$, et al. The stem cell niche in glioblastoma: from fundamental aspects to targeted therapies. Bull Cancer. 2015; 102: 24-33. http://dx.doi.org/10.1016/j.bulcan.2014.07.001

[8] PARSONS DW, JONES S, ZHANG X, LIN JC, LEARY RJ, et al. An Integrated genomic analysis of human glioblastoma multiforme. Science. 2008; 321: 1807-12. http://dx.doi. org/10.1126/science. 1164382

[9] DA SILVA R, UNO M, MARIE SK, OBA-SHINJO SM. LOX expression and functional analysis in astrocytomas and impact of IDH1 Mutation. PLoS One. 2015; 10: e0119781. http:// dx.doi.org/10.1371/journal.pone.0119781

[10] CALABRESE C, POPPLETON H, KOCAK M, HOGG TL, FULLER C, et al. A perivascular niche for brain tumor stemcells. Cancer Cell. 2007; 11: 69-82. http://dx.doi.org/10.1016/j. $\underline{\text { ccr.2006.11.020 }}$

[11] BROOKS MD, SENGUPTA R, SNYDER SC, RUBIN JB. Hitting Them WhereThey Live: Targeting the Glioblastoma Perivascular Stem CellNiche. Curr Pathobiol Rep. 2013; 1: 101-10. http://dx.doi.org/10.1007/s40139-013-0012-0

[12] SCHOLER HR, RUPPERT S, SUZUKI N, CHOWDHURY $\mathrm{K}$, GRUSS P. New type of POU domain in germ line-specific protein Oct-4. Nature. 1990; 344: 435-9. http://dx.doi. org/10.1038/344435a0

[13] BUITRAGO W, ROOP DR. Oct-4: the almighty POUripotent regulator? J Invest Dermatol. 2007; 127: 260-2. http://dx.doi. org/10.1038/sj.jid.5700654

[14] SHI J, SHI W, NI L, XU X, SU X, et al. OCT4 is epigenetically regulated by DNA hypomethylation of promoter and exon in primary gliomas. Oncol Rep. 2013; 30: 201-6.

[15] ATLASI Y, MOWLA SJ, ZIAEE SA, BAHRAMI AR. OCT-4, an embryonic stem cell marker, is highly expressed in bladder cancer. Int J Cancer. 2007; 120: 1598-602. http://dx.doi. org/10.1002/ijc.22508

[16] WEBSTER JD, YUZBASIYAN-GURKAN V, TROSKO JE, CHANG CC, KIUPEL M. Expression of the embryonic transcription factor Oct4 in canine neoplasms: a potential marker for stem cell subpopulations in neoplasia. Vet Pathol, 2007; 44: 893-900. http://dx.doi.org/10.1354/vp.44-6-893

[17] DU Z, JIA D, LIU S, WANG F, LI G, et al. Oct4 is expressed in human gliomas and promotes colony formation in glioma 
cells. Glia. 2009; 57: 724-33. http://dx.doi.org/10.1002/ glia.20800

[18] BASTIEN JI, MCNEILL KA, FINE HA. Molecular characterizations of glioblastoma, targeted therapy, and clinical results to date. Cancer. 2015; 121: 502-16. http://dx.doi.org/10.1002/ cncr.28968

[19] EHRICHM, TURNER J, GIBBS P, LIPTON L, GIOVANNETI $\mathrm{M}$, et al. Cytosine methylation profiling of cancer cell lines. Proc Natl Acad Sci USA. 2008; 105: 4844-9 http://dx.doi. org/10.1073/pnas.0712251105

[20] CARLESS MA. Investigation of genomic methylation status using methylation- specific and bisulfite sequencing polymerase chain reaction. Methods Mol Biol. 2015; 1288: 193-212. http://dx.doi.org/10.1007/978-1-4939-2474-5 11

[21] CANKOVIC M, MIKKELSEN T, ROSENBLUM ML, ZARBO RJ. A simplified laboratory validated assay for MGMT promoter hypermethylation analysis of glioma specimens from formalin-fixed paraffin-embedded tissue. Lab Invest. 2007; 87: 392-7. http://dx.doi.org/10.1038/labinvest. 3700520

[22] TANAKA S, AKIMOTO J, NARITA Y, OKA H, TASHIRO T. Is the absolute value of $\mathrm{O}(6)$ - methylguanine-DNA methyltransferase gene messenger RNA a prognostic factor, and does it predict the results of treatment of glioblastoma with temozolomide? J Neurosurg. 2014; 121: 818-26. http://dx.doi. org/10.3171/2014.6.JNS132535

[23] COCK-RADA A,WEITZMAN JB. The methylation landscape of tumour metastasis. Biol Cell. 2013; 105: 73-90 http://dx.doi. org/10.1111/boc.201200029

[24] PICCOLO FM, FISHER AG. Getting rid of DNA methylation. Trends Cell Biol. 2014; 24: 136-43 http://dx.doi.org/10.1016/j. $\underline{\text { tcb.2013.09.001 }}$

[25] AL-KHTIB M, BLACHERE T, GUÉRIN JF, LEFEVRE A. Methylation profile of the promoters of Nanog and Oct4 in ICSI human embryos. Hum Reprod. 2012; 27: 2948-54 http:// dx.doi.org/10.1093/humrep/des284

[26] LI JY, PU MT, HIRASAWA R, LI BZ, HUANG YN, et al. Synergistic function of DNA methyltransferases Dnmt3a and Dnmt $3 \mathrm{~b}$ in the methylation of Oct 4 and Nanog. Mol Cell Biol. 2007; 27: 8748-59. http://dx.doi.org/10.1128/MCB.01380$\underline{07}$

[27] FELDMAN N, GERSON A, FANG J, LI E, ZHANG Y, et al. G9a-mediated irreversible epigenetic inactivation of Oct-3/4 during early embryogenesis. Nat Cell Biol. 2006; 8: 188-94. http://dx.doi.org/10.1038/ncb1353

[28] BIGNER SH, MATTHEWS MR, RASHEED BK, WILTSHIRE RN, FRIEDMAN HS, et al. Molecular genetic aspects of oligodendrogliomas including analysis by comparative genomic hybridization. Am J Pathol. 1999; 155: 375-86. http://dx.doi.org/10.1016/S0002-9440(10)65134-6

[29] JANSENGA, MIHALIK SJ, WATKINS PA, MOSER HW, JAKOBS C, et al. Phytanoyl-CoA hydroxylase is present in human liver, located in peroxisomes, and deficient in Zellweger syndrome: direct, unequivocal evidence for the new, revised pathway of phytanic acid alpha-oxidation in humans. Biochem Biophys Res Commun. 1996; 229: 205-10. http:// dx.doi.org/10.1006/bbrc.1996.1781
[30] TABATABAI G, WELLER M. Glioblastoma stem cells. Cell Tissue Res. 2011; 343: 459-65. http://dx.doi.org/10.1007/ s00441-010-1123-0

[31] SAMPETREAN O, SAYA H. Characteristics of glioma stem cells. Brain Tumor Pathol. 2013; 30: 209-14. http://dx.doi. org/10.1007/s10014-013-0141-5

[32] LUTHER N, CHEUNG NK, SOULIOPOULOS EP. Interstitial infusion of glioma- targeted recombinant immunotoxin 8H9scFv-PE38. Mol Cancer Ther. 2010; 9: 1039-46 http:// dx.doi.org/10.1158/1535-7163.MCT-09-0996

[33] DAVID CN. Interstitial stem cells in hydra: multipotency and decision-making. Int J Dev Biol. 2012; 56: 489-97. http:// dx.doi.org/10.1387/ijdb.113476cd

[34] VAZIRANI J, BASU S, KENIA H, ALI MH, KACHAM S, et al. Unilateral partial limbal stem cell deficiency: contralateral versus ipsilateral autologous cultivated limbal epithelial transplantation. Am J Ophthalmol. 2014; 157: 584-90. http:// dx.doi.org/10.1016/j.ajo.2013.11.011

[35] ESTRADA-BERNAL A, PALANICHAMY K, RAY CHAUDHURY A, VAN BROCKLYN JR. Induction of brain tumor stem cell apoptosis by FTY720: a potential therapeutic agent for glioblastoma. Neuro Oncol. 2012; 14: 405-15. http://dx.doi. org/10.1093/neuonc/nos005

[36] CHARLES N, HOLLAND EC. The perivascular niche microenvironment in brain tumor progression. Cell Cycle. 2010; 9: 3012-21. http://dx.doi.org/10.4161/cc.9.15.12710

[37] DING J, XU H, FAIOLA F. Oct4 links multiple epigenetic pathways to the pluripotency network. Cell Res. 2012; 22: 155-67. http://dx.doi.org/10.1038/cr.2011.179

[38] IKUSHIMA H, TODO T, INO Y, TAKAHASHI M, SAITO $\mathrm{N}$, et al. Glioma-initiating cells retain their tumorigenicity through integration of the Sox axis and Oct4 protein. J Biol Chem. 2011; 286: 41434-41 http://dx.doi.org/10.1074/jbc. M111.300863

[39] PESTEREVA E, KANAKASABAI S, BRIGHT JJ. PPAR $\gamma$ agonists regulate the expression of stemness and differentiation genes in brain tumor stem cells. Br J Cancer. 2012; 106: 1702-12. http://dx.doi.org/10.1038/bjc.2012.161

[40] CHAKRABORTY S, KANAKASABAI S, BRIGHT JJ. Constitutive androstane receptor agonist CITCO inhibits growth and expansion of brain tumor stem cells. Br J Cancer. 2011; 104: 448-59. http://dx.doi.org/10.1038/sj.bjc.6606064

[41] FAKHREDDINE MH, MAHAJAN A, PENAS-PRADO M. Treatment, prognostic factors, and outcomes in spinal cord astrocytomas. Neuro Oncol. 2013; 15: 406-12 http://dx.doi. org/10.1093/neuonc/nos309

[42] MITCHELL R, SZABO E, SHAPOVALOVA Z, ASLOSTOVAR L, MAKONDO K, et al. Molecular evidence for OCT4- induced plasticity in adult human fibroblasts required for direct cell fate conversion to lineage specific progenitors. Stem Cells. 2014; 32: 2178-87. http://dx.doi.org/10.1002/stem.1721

[43] LIU Y, MUKHOPADHYAY P, PISANO MM, LU X, HUANG $\mathrm{L}$, et al. Repression of Zeb1 and hypoxia cause sequential mesenchymal-to-epithelial transition and induction of aid, Oct4, and Dnmt1, leading to immortalization and multipotential reprogramming of fibroblasts in spheres. Stem Cells. 2013; 31: 1350-62. http://dx.doi.org/10.1002/stem.1382 